\title{
På tanken: Kultur som poetik
}

\author{
Søren Frimann \& Christian Jantzen
}

\begin{abstract}
I artiklen analyserer vi en eksemplarisk case for at belyse generelle forhold ved hverdagslige interaktioner. I vort tilfælde drejer det sig om de læringsmæssige effekter, som afvigelsen fra et opøvet interaktionsmønster skaber. Det forhold, at afvigelsen kan danne grundlag for nye måder at 'gøre' interaktionen på - det er 'kultur'. Kultur er noget, der 'hænder' på grund af faktiske interaktioner i konkrete situationer. Vi illustrerer dette kulturbegreb ved at analysere en kort interaktion, som udspandt sig på en tankstation nogle år tilbage. Vi vil prøve at vise, hvordan den ene deltagers (nemlig kundens) forventninger er rodfæstet i tidligere erfaringer, hvordan interaktionens forløb skuffede disse forventninger, hvorledes dette bevirkede, at situationen måtte omdefineres, hvorledes dette påvirkede deltagerens selvbillede og hvad det kan betyde for deltagerens fremtidige bidrag til lignende interaktioner i form af justerede erfaringer. I situationen skete der nærmest intet, men alligevel hændte der tilstrækkeligt til, at også denne interaktion - uventet og utilsigtet - førte til 'kulturarbejde'. Kultur er nemlig noget, 'der gøres': dette 'noget' er pragmatisk - og som sådan poetisk og performativt.
\end{abstract}

Key words: Kultur, poetik, performativitet, interaktionsanalyse, kulturanalyse.

Please cite this article as: Frimann, S. \& Jantzen, C. (2010). På tanken: Kultur som poetik. Qualitative Studies, 1(1): 48-74.

\section{"Hvad kan jeg gøre for Dem?"}

Hvordan kan det være, at vi til tider taler forbi hinanden, selvom vi deler mange fælles erfaringer, og endda på trods af, at vi muligvis har kendt hinanden i lang tid? Og hvordan kan det omvendt være, at jeg kan gøre mig forståelig for dig og også er i stand til at forstå dine bevæggrunde og hensigter, selvom vi netop ikke kan observere hinandens individuelle motiver og erfaringer? To simple spørgsmål, som ikke desto mindre peger ind mod de to parallelle 'universer', som vi som socialt situerede individer lever i og med, så snart vi interagerer med hinanden. Vi handler på den ene side ud fra et mentalt univers, begrundet $\mathrm{i}$ egne erfaringer, som er unikke for hvert individ, men er usynlige for andre. Det er derfor, vi så ofte misforstår hinanden. På den anden side handler vi i forhold til et socialt univers, hvor meningen med tingene og situationen er kommunikeret og kommunikerbar: hvor vi altså kan deltage i og langt hen ad vejen - deles om en konventionel og fælles forståelse.

Det spændende ved menneskelig handlen er helt elementært, at disse to universer hænger sammen, så snart vi interagerer med verdenen. Sammenhængen findes i hverdagslivet og leves mere eller mindre gnidningsløst ud der. Den findes imidlertid i langt mindre grad i de videnskaber, som har sat sig til opgave at undersøge forudsætninger og konsekvenserne af menneskelig handling. Sociologien har i løbet af det sidste århundrede udforsket de gruppemæssige og socialisationsbetingede mønstre for kollektiv adfærd. Psykologien - og ikke mindst kognitionsvidenskaben - har i samme tidsrum blotlagt de individuelle strukturer for blandt andet erindring og viden. Transaktionerne mellem disse to universer er imidlertid $\mathrm{i}$ stigende grad gledet ud af billedet og erstattet af en ufrugtbar dualisme. Sociologien har - groft sagt - udviklet sig i anti-mentalistisk retning, hvorimod psykologien er blevet domineret af en situationsuafhængig betragtningsmåde. 
Det er dog netop disse transaktioner, som er retningsgivende for menneskelig handling (det mentale univers) og samtidig gør disse handlinger meningsfulde (det sociale univers). I det følgende vil der derfor blive sat fokus på præcis disse transaktioner. Vi vil argumentere for, at 'kultur' er den praksis, som oversætter mellem hverdagens sociale situationer og private erfaringer. Kultur vedrører spørgsmålet om, hvordan oplevelser i konkrete interaktioner kan foranledige til dannelsen eller opdyrkningen (latin: cultus) af nye erfaringer, som så atter er grundlag for fremtidige handlinger. Argumentationen bygger på en tese om, at denne kulturelle praksis er poetisk, og at denne praksis er et hverdagsfænomen. Den finder sted, når eller så snart en af interaktionens deltagere begynder at hæfte sig ved interaktionens form (dens "hvorledes") frem for ved dens indhold eller tematik (interaktionens "hvad, hvem og hvorfor").

Hverdagen er kendetegnet ved, at der hænder en masse, uden at der egentlig sker en del. Vi interagerer mere eller mindre ubesværet med andre mennesker og med genstandsverdenen, og derfor kan vi ved dagens afslutning ofte kun sporadisk rekonstruere nogle få interaktioners omtrentlige forløb. Men det hænder, at en interaktion fæstner sig et sted i hukommelsen, så vi husker den detaljeret og sansemættet, også selvom egentlig intet skete. Her er et eksempel på en sådan interaktion, som fandt sted på en tilfældig benzintank en hverdagsaften i 2001. Det er denne i og for sig banale hændelse som i det følgende vil være vores case ${ }^{1}$

\author{
Ekspedient: Goddag Hr. Hvad kan jeg gøre for Dem? \\ Kunde: $\quad J e g$ har tanket benzin på stander 5 \\ Ekspedient: Det bliver 354,75. Ellers andet? \\ (...udeladelse...) \\ Ekspedient: De må fortsat have en god dag, $\mathrm{Hr}$. \\ Kunde: $\quad$ Tak
}

Intet skete, udover at ekspedienten fik sine penge og kunden sin benzin. Men alligevel hændte der noget 'mere', der fik kunden til at huske interaktionen som en dårlig oplevelse, fordi han ikke tacklede situationen helt tilfredsstillende. Han kom i vildrede med hensyn til, hvordan han skulle matche ekspedientens høflighed. I vores optik behandler kulturanalyse denne slags banale og alligevel unikke interaktioner i bestemte situationer, hvor der hænder en del uden, at noget afgørende er på spil. 'Situation' og 'interaktion' er således kernebegreber i vores analytiske praksis.

En situation er et stedsbundet hændelsesforløb med en start og en slutning, der er struktureret ud fra et overordnet tema. Enhver situation er steds- og tidsbundet, hvilket betyder, at den er konkret. Situationens tematik udtrykker dog, at hændelserne handler om noget mere alment, hvad enten det fx er at hænge ud eller forrette et ærinde, nå et mål eller score en gevinst. Der findes altså en lang række situationstyper, hver især kendetegnet ved en egen tematik. Tematikken er definerende for typen. Den konkrete situation er derimod en specifik udfyldning af tematikken. Ingen konkret situation er fuldstændig identisk med andre - tidligere eller senere - situationer, men den ligner mange andre situationer. Indkøbet i supermarkedet i dag ligner indkøbet andre dage og $\mathrm{i}$ andre supermarkeder og endda $\mathrm{i}$ betydelig grad indkøb $\mathrm{i}$ almindelighed. Fordi den konkrete situation svarer til den almene (eller mere abstrakte) situationstype, kan indkøbet som regel ske ubesværet.

Individet agerer i situationen, på situationen og i forhold til andre deltagere (genstande og mennesker), der ligeledes agerer og reagerer i og på situationen. En interaktion er den 
udveksling, der opstår mellem mennesker og mellem mennesker og genstande i den konkrete situation. Interaktionen er det faktiske forløb, som de situerede deltagere realiserer, mens de handler situationsspecifik. Enhver situation åbner for mange mulige forløb. Den faktiske interaktion er dermed en konkret udmøntning af dette potentiale, hvilket specificerer den konkrete situations egenart: lige nu er vi i denne steds- og tidsbundne situation, som godt nok ligner mange andre situationer, men i grunden er unik.

Da den faktiske interaktion er en udveksling, danner den et mønster, som fastlægger de deltagendes position og roller i forhold til hinanden. Dette mønster er en relation. I tråd med Simmel (1998) må interaktioner derfor ikke kun betegnes som sociale, men som selve grundlaget for samfundsmæssighed. Samfundet vokser frem af vekselvirkningerne på aktørernes mikroniveau, og samfundets institutioner (skoler, politi, politik og meget mere) er formaliseringer og generaliseringer af de relationer, som er blevet dannet på mikroniveau (jf. Berger og Luckmann, 1966). Et særligt træk ved Simmels sociologi er desuden, at han insisterede på, at individer interagerer med hinanden ud fra individuelle erfaringer og tilbøjeligheder og med henblik på at nå både private og fælles mål. Simmels sociologi er således mentalistisk, og han udviklede denne teori i undersøgelsen af hverdagens banaliteter: af hilsner, dørhåndtag, flirt etc. Den er ydermere en formal sociologi. Den er optaget af, hvorledes sociale situationer konstitueres, forløber og afvikles. Den undersøger derfor de alt andet end banale regler, som får hverdagens trivialiteter til at hænde: fx den viden eller de færdigheder, vi bruger for at kunne gebærde os på tankstationen.

Hensigten med denne slags undersøgelser er ikke at få en mere fuldstændig viden om tankstationen (situationens "hvad"), men om hoorledes interaktionens mønster og regler er definerende for både individet (selvforståelse, identitet) og samværet eller endog samfundet (relationen, institutionen). Denne form for mentalistisk og formal mikrosociologi er derfor optaget af spørgsmålet om, hvordan hverdagslivet overhovedet er muligt. Vi abonnerer på denne tradition, især i den udformning den har fået hos Garfinkel (1967), der undersøger den til dels kognitivt baserede metodologi, som almindelige folk anvender for at skabe sammenhæng i hverdagen (deraf navnet "etnometodologi"), og - ikke mindst - hos Goffman $(1959,1967,1995)$, som analyserer de hverdagsstrategier, der bruges for at præsentere sig selv og for at opretholde ansigt-til-ansigt interaktioner. Disse teorier går imod den sociologiske hovedstrøm, fordi de adresserer, at mentale processer i form af "sense making" er forudsætningen for aktørers deltagelse i sociale situationer (jf. fx Heritage, 1984, p. 37ff; van Dijk, 2009, p. 100ff.). Senere bidrag til den formale sociologi har derimod tenderet mod at fokusere enten på interaktionens sproglige, men "kontekstløse" regeldannelse - fx Schegloffs konversationsanalyse (1991) - eller dens indlejring i samfundsmæssige diskurser (fx Fairclough, 1995).

I lighed med vores inspirationskilder analyserer vi en eksemplarisk case for at belyse generelle forhold ved hverdagslige interaktioner. I vort tilfælde drejer det sig om de læringsmæssige effekter, som afvigelsen fra et opøvet interaktionsmønster skaber. Det forhold, at afvigelsen kan danne grundlag for nye måder at 'gøre' interaktionen på - det er 'kultur'. Kultur er noget, der 'hænder' på grund af faktiske interaktioner i konkrete situationer. Vi vil i det følgende forsøge at illustrere dette kulturbegreb ved at analysere den korte interaktion, som udspandt sig på tankstationen nogle år tilbage. Vi vil prøve at vise, hvordan den ene deltagers (nemlig kundens) forventninger er rodfæstet i tidligere erfaringer, hvordan interaktionens forløb skuffede disse forventninger, hvorledes dette bevirkede, at situationen måtte omdefineres, hvorledes dette påvirkede deltagerens selvbillede og hvad det kan betyde for deltagerens fremtidige bidrag til lignende interaktioner i form af justerede erfaringer. Som det fremgår af ordvekslingen, så skete 
der nærmest intet, men alligevel hændte der tilstrækkeligt til, at også denne interaktion uventet og utilsigtet - førte til 'kulturarbejde'. Kultur er nemlig noget, 'der gøres': dette 'noget' er pragmatisk - og som sådan poetisk og performativt.

\section{Det pragmatiske kulturbegreb}

Den centrale antagelse for et pragmatisk kulturbegreb er, at kultur ikke er noget tillært, overleveret eller institutionaliseret. Kultur er ikke, som det ellers antages i den antropologiske tradition, noget individer vanemæssigt 'er' del af (fx Tyler, 1873; Williams, 1958). Kultur er ej heller en kanon af særligt værdifulde artefakter, som individer 'har' eller socialt og statusmæssigt set kan have adgang til, hvilket er grundtanken i det æstetiske kulturbegreb (jf. Jensen, 1989). Kultur er derimod den proces, hvor mennesker lærer noget ved at handle i situationer, og derfor har med sig som erfaring eller vane næste gang, de skal handle i en lignende situation. Kultur er noget, 'der gøres': den indsigt, der opstår, eller den lektie, der læres, mens og idet man handler. I det pragmatiske begreb er kultur en erkendelsesproces i forhold til faktiske erfaringer med sociale situationer. Processen beror på menneskets evne og vilje til at tage stilling til verden (Jantzen, 2005, p. 98). Denne proces udvikler eller forandrer, hvad vi efterfølgende vil og skal kunne eller bør og kan ville. Vi får præciseret vores forventninger til situationen, tunet vores færdigheder i interaktionen, nuanceret vores emotionelle parathed, redefineret vores position i relationer eller vores selvforståelse (identitet). Kultur er således de færdigheder, hensigter, idealer, ønsker og længsler, vi opdyrker (latin: cultivare) som konsekvens af situerede handlinger, hvilket forbereder os på kommende handlinger.

Kultur lærer at indstille os på fremtiden ved at bearbejde fortidens hændelser. Når vi netop kan forholde os ubesværet i mange situationer, skyldes dette, at fortolkningen med tiden og ved trial and error - altså ved aktiv deltagelse i mangfoldige interaktioner - er blevet indarbejdet som en kropslig rutine og mental disposition - som fx habitus (Bourdieu, 1990). Kultur gør det muligt at erkende de forventningsbrud, som den konkrete situation måtte byde på, bearbejde disse oplevelser refleksivt (som ny fortolkning) og derved omdanne dem til nye forholdsregler, der med tiden kan blive et selvfølgeligt erfarings- og motivationsgrundlag for handlen (jf. Jantzen og Vetner, 2007b). Kultur 'gøres', fordi forventninger de-automatiseres: kompetencer og intentioner, begrundet i eksisterende erfaringer ('det gjorte'), udfordres. Denne 'gøren' er ny erkendelse, som sker med henblik på erfaringsdannelse. Hvis denne proces 'lykkes', vil de nyerhvervede kompetencer og intentioner hen ad vejen automatiseres som et nyt selvfølgeligt erfaringsgrundlag.

Vi vil i det efterfølgende vise, hvorledes kultur som forandrings- og tilpasningspraksis svarer til det poetiske sprogs virkemidler. Sprogets poetiske funktion opstår ifølge traditionen fra den russiske formalisme i en dynamisk vekselvirkning mellem de-automatisering og dannelsen af nye konventioner (Sklovskij, 1969). Denne funktion er kendetegnet ved, at opmærksomheden vendes fra budskabets reference til den ydre verden eller fra henvisningen til afsenderens intentioner eller modtagerens reaktioner ind mod tekstens egen formmæssige karakteristika (Jakobson, 1960). Det er tekstens 'tekstlighed', der kommer i fokus, ikke dens indhold eller umiddelbare hensigt. Konsekvensen af en sådan poetisk refokusering er, at situationen må omdefineres. Den handler fx ikke længere blot om et simpelt bytteforhold på en tankstation, der understøttes af en verbal udveksling, men også - og især - om hvad og hvorledes, noget kan, bør eller må siges i denne udveksling. Det handler altså om 'teksten' frem for pengetransaktionen. Derved sættes den gamle kontekst for interaktionen på spil og bringes en ny på banen. 
Denne refokusering er performativ. Interaktionens vante gang bliver afsporet, idet udsigelsens stil - ordvalget, intonationen, metrikken etc. - kommer i centrum. Det 'gør' noget ved deltagerne. Spørgsmål, som normalt ikke bør stilles, hvis interaktionen ellers skal forløbe rutinemæssigt, trænger sig på: "Hvad sker der i grunden her?", "Hvem er 'jeg' i dette spil?" eller "Hvad vil hun/han 'mig'?". Performativitet er netop kendetegnet ved denne form for refleksivitet, der drager den oprindelige fortolkningsramme i tvivl (Bauman og Briggs, 1990, p. 73). Lige som interaktionen poetisk peger tilbage mod 'tekstligheden', så peger situationen performativt tilbage mod deltagerne: mod deres erfaringer, intentioner og motiver. Handlingens sociale og mentale univers de-automatiseres, så de skal fortolkes anderledes, end deltagerne havde regnet med eller er vant til.

Det er her kultur kommer ind i billedet. Kultur er mellemleddet mellem gamle vaner og nye erfaringer: altså erfaringsbaseret læring, idet nye erkendelser sker på baggrund af etablerede vaner og refleksivt foranlediger nye vaner (Dewey, 1922; jf. også Brinkmann, 2008). Da kultur udspringer af faktiske interaktioner, må denne læring samtidig siges at være situeret (Lave og Wenger, 2003). Det er oplevelser med relationer i konkrete situationer, der er kulturskabende, og altså kan forandre deltagerens selvforståelse og udvide aktørens kompetencer. Dermed kan kultur som læringsform fremdeles relateres til kognitiv udvikling, som beskrevet af Vygotsky (1978). Idet kultur internaliserer interpersonelle oplevelser, udvikles individet og tilpasses de ændrede historiske og sociale omgivelser.

En vigtig teoretisk implikation af vores kulturbegreb er, at vi forstår interaktioner som styret af to principper. Et økonomiprincip tilsiger deltagere at få det meste ud af situationen med færrest mulige anstrengelser. Interaktionen skal derfor være så ubesværet som muligt, og det fremmes ved, at deltagerne kan trække på tidligere erfaringer: på etablerede kompetencer, på forståelser af situationen i form af fx scripts (Schank og Abelson, 1977) og mentale modeller (van Dijk, 1985) samt på selvbiografisk erindring af specifikke episoder. En del af kulturanalysen består derfor i at afdække dette økonomiserende kognitive grundlag. Det er rutiner.

Et andet princip, som man kunne kalde et prægnansprincip, tilsiger deltagere at erhverve størst mulig personlig relevans i relationen med færrest mulige omkostninger. Interaktionen skal derfor give den enkelte deltager mulighed for at pointere sit eget bidrag så optimalt som muligt. Det drejer sig om at skabe det rette indtryk på de andre for enten at undgå konflikt eller at opnå størst mulig gyldighed: altså "impression management" (Goffman, 1959). En anden del af kulturanalysen drejer sig derfor om at vise disse positioneringsmekanismer.

Disse to principper er, som vores analyse vil vise, langt fra altid kongruente. Mange faktiske interaktioner vil derfor være præget af, at disse to principper handles af mod hinanden, så den situationelle gevinst sker med mindst mulig relationelt tab (og omvendt). Deltagere i interaktionen vil således typisk teste hinanden for at undersøge, hvilke gevinster er mulige og hvilke tab, der kan befrygtes. Det forhold, at interaktioners forløb som regel tillader en vis improvisation inden for de situationelle og relationelle rammer, fremmer denne testning og bevirker, at erfaring bliver til ved hypotesedannelse, -testning og -justering - altså netop trial and error.

I den analytiske udmøntning af vores pragmatiske kulturbegreb vægter vi de kompetencer og intentioner, som er på spil i situerede interaktioner. Disse analyseres tekstlingvistisk. I forlængelse af den strukturelle lingvistik undersøges interaktioner og konkrete situationer som 
en realisering af de paradigmatiske og syntagmatiske muligheder, som er indeholdt $i$ et abstrakt sprogsystem (Jakobson, 1956; Saussure, 1985). Et paradigme angiver lighedstræk mellem forskellige betydningselementer, hvorimod et syntagme angiver reglerne for sammenkædning af elementer fra forskellige paradigmer. Betydning dannes således ved at selektere et element fra et paradigme og kombinere dette element med valg fra andre paradigmer. Denne kombination er et syntagme. De paradigmatiske selektioner og syntagmatiske kombinationer hviler på koder: dvs. konventionelt definerede regelsæt for hvordan betydningselementer syntaktisk, semantisk og pragmatisk er relateret til hinanden (jf. Morris, 1938). Vi trækker på Hymes (1974) med henblik på at analysere evnen til at forholde sig refleksivt og kommunikativt kompetent til interaktionens kode og på den kognitive semantik for at undersøge det kodekendskab, som situationsfornemmelse kræver (fx Schank og Abelson, 1977; Johnson-Laird, 1983; van Dijk, 1985). Diskurspsykologien bruges til at analysere den subjektivitet, som situationsbestemte valg og fravalg positionerer (Harré og van Langenhove, 1999).

\section{Situation og kompetence}

At gebærde sig ubesværet på tankstationen forudsætter, at man er kompetent til at begå sig i situationen. Man bør have kendskab til, hvad hensigten med tankstationer er, hvad man kan forvente af tjenester sådan et sted, hvilken form for transaktion og hvilken slags varer, stationen tilbyder, og hvad der til gengæld forventes af ens eget bidrag. Alt dette er forudsat, og da de fleste af os har en 'miniteori' om tankstationerne og deres samfundsmæssige betydning, volder situationen sjældent større besvær. Pointen er, at denne 'miniteori' er nødvendig for at være kompetent, samt at den beror på en kognitiv model, som bygger på erfaringsdannelse som følge af en lang række forudgående interaktioner i lignende situationer. Det er erfaringer, gjort for egen regning, som synes fælles, men er private: netop vores egne, unikke mentale forestilling, lagret i vores egen selvbiografiske hukommelse som viden om den socialt almenkendte kategori 'tankstation'. Denne viden er en mental model, som er en subjektiv repræsentation af en begivenhed eller situation i den autobiografiske hukommelse (Johnson-Laird, 1983; van Dijk, 1985), eller et script, som er en kognitiv drejebog for, hvordan situationer typisk forløber (Schank og Abelson, 1977).

Vores kognitive situationsmodel informerer os om tankstationens hvad (benzin og dagligdagsvarer, evt. bespisning) og hvorfor (transport, køb og salg mm.). Modellen er på det punkt en mini-samfundsteori, der giver os nogle rimeligt sikre antagelser om, hvad der vi kan forvente os og hvad vores rolle forventes at være. Men den informerer os også om interaktionens hvordan, og rummer som sådan en mini-kommunikationsteori med antagelser om, hvad vi bør eller kan gøre i forhold til de andre kunder og ekspedienten (altså i forhold til relationen) og i hvilken rækkefølge, vi bør eller kan gøre hvad (altså i forhold til situationen) (jf. Hymes, 1974).

Den kognitive model er som sådan en abstraktion, som dannes ud fra erfaringer med konkrete situationer. Den viser de generelle træk, som definerer det prototypiske ved denne art situationer. Denne abstraktion kalder vi i det efterfølgende situationstype (Frimann, 2004, p. 35; Halliday og Matthiesen, 1999). Situationstypen 'tankstation' giver os en rimelig sikker fornemmelse for, hvordan vi bør agere for at virke kompetent. Kompetence er ikke mindst et spørgsmål om at kunne vælge uhensigtsmæssige handlinger fra. Selv om vi som kompetente sprogbrugere kan generere en uendelig mængde grammatisk og semantisk korrekte sætninger (Chomsky, 1966), så ved vi af erfaring, at vores valgmuligheder på tanken faktisk er begrænset. Det kan vises i følgende eksempel viser, hvor de valg, der ikke er mulige, hvis vi skal forekomme kompetente, er markeret med *. 


\author{
Ekspedient: Hvad skulle det være? \\ Kunde: \\ A: * Jeg vil gerne hore din mening om statsministeren. \\ $B:{ }^{*} J e g$ vil gerne købe benzin til 50 øre literen. \\ C: *Vil du med ud at spise $i$ aften? \\ D: Jeg har tanket benzin på stander 3 og så vil jeg gerne have 20 Prince.
}

Ytring A, B eller C viser et misforhold mellem ekspedientens og kundens definition af situationen. Der er ikke længere tale om ekspedition, men om fx kurmageri (ytring $C$ ), en østerlandsk basar (ytring B) eller en art opinionsundersøgelse (ytring A). For at interaktionen kan forløbe gnidningsfrit og næsten automatisk, skal deltagerne således være enige om, hvilken situationstype de deltager i, og de skal vide, hvad dette kræver af bidrag (roller, ytringer) fra deres side. Hvis en af deltagerne bryder forventningerne, må de andre overveje, enten om deres egen situationsfornemmelse svigtede ( $\mathrm{f} x$ at der godt må scores, mens der tankes op) eller hvor vidt regelbryderen er social eller psykisk tilregnelig (kompetence) eller kommunikativt oprigtig (jf. Grice, 1975).

Der er altså grænser for de ytringer, som ekspedient og kunde frit kan frembringe inden for situationens rammer. Disse begrænsninger skyldes også forventningerne til de relationelle roller i ekspeditionssituationen: dvs. i forhold til hvordan ekspedienten og kunden kan optræde overfor hinanden. Det kan illustreres med et eksempel, hvor kunden starter interaktionen.

Kunde:

A: *Hvad kan jeg hjælpe dig med?

B: Har I citronmåner?

Ekspedient:

B: Ja, de er på tredje hylde på reolen til venstre for køleskabet.

I A overtager kunden ekspedientens rolle ved at gøre et udspil om salgsindgåelse, mens kunden i eksempel B fremsætter en salgsforespørgsel. A er derfor ret beset umulig i situationen. Disse eksempler illustrerer en generel pointe for interaktion i almindelighed. Situationstypen præformaterer deltagernes handlinger. Der er grænser for, hvad man kan tale om og hvilke taleroller man kan indtage, hvis ytringerne skal være meningsfulde i situationen. For det tredje indeholder situationstypen retningslinjer for interaktionernes faktiske forløb, således at der kun findes et begrænset antal adækvate valgmuligheder på bestemte steder i sekvensen. Det kan illustreres med følgende varianter på det oprindelige eksempel.

Ekspedient: Det bliver 354,75. Ellers andet?

Kunde: Nej, tak. Værsgo' her er 354,75.

Ekspedient: Tak.

A: ${ }^{*}$ Er De sikker på, at De har husket det hele?

B: * Hvad skulle der være?

C: Har De forresten set at der er tilbud på bilvask til halv pris i dag?

D: Farvel og ha' en god dag.

Varianterne viser, at deltagernes bidrag ikke kan fremsættes vilkårligt i interaktionen, da det ellers ville pege tilbage på en af deltagernes (her: ekspedientens) manglende kompetence til at 
håndtere situationstypen. Situationens mulighedsfelt er for ekspedientens vedkommende indsnævret efter påbegyndelsen af betalingssekvensen: faktisk kan ekspedienten kun indlede en afskedssekvens (ytring D) eller henlede kundens opmærksomhed på tilbud, som kunden måtte have overset, hvilket potentielt indleder en ny ekspedition (ytring C). I disse sekvenser er kundens frihed langt større, da han uden videre kan påbegynde yderligere ekspeditionssekvenser, fx.:

"Jeg glemte for resten, at jeg også skulle have en pose kaffe".

Indtil nu har vi undersøgt aspekter af den minikommunikationsteori, som deltagerne bruger i deres interaktion på tanken. Med en sådan miniteori in mente har deltagerne hver for sig dannet hypoteser om hvilken situation, de befinder sig i, og hvad der følgelig er påkrævet af dem. Det er vores påstand, at alle interaktioner beror på denne slags implicitte hypoteser, og endvidere at enhver interaktion må siges at være aktivt hypotesetestende. De andre deltageres kompetente handlinger i interaktionen - $\mathrm{fx}$ deres modtræk, deres turtagning i interaktionen og deres anerkendelse af vores indspil - bekræfter vores hypotese, så situationen faktisk kan verificeres. I denne proces skabes der samklang mellem de deltagende, idet de afstemmer deres handlinger i forhold til hinanden. Det er på den måde, 'fælleshed' tilvejebringes.

Men 'fælleshed' er ikke altid interaktionens konsekvens. Ofte sker det, at kravene til adfærden ikke opfyldes eller at adfærden er tvetydig eller vanskelig at tolke. Så må enten hypotesen eller selve miniteoriens grundlag justeres. I det andet tilfælde må vores oprindelige definition af situationstypen problematiseres eller forkastes og suppleres eller erstattes af en anden og muligvis mere kompleks: som fx når kurmageri ("Vil du med ud at spise i aften") blandes ind i en ellers tilsyneladende banal økonomisk udveksling. I så fald må vi genoverveje, hvad der 'egentlig' er på færde - altså hvad situationen i grunden drejer sig om. I det første tilfælde må derimod dele af vores hypotese ændres, afvises eller udvides, da vores egen eller modpartens viden ikke synes at slå til i forhold til situationstypen. Dette hænder, når der opstår tvivl om en af deltagernes kompetencer. Dette rokker ikke som sådan ved den anden parts opfattelse af situationstypen, men i høj grad ved opfattelsen af relationen til den 'inkompetente'. Hvis den anden part tilsyneladende ikke er fuldt tilregnelig, skal der bruges anden viden (flere kompetencer) for at redde situationen.

Det handler om kompetencer. Men hvordan afgøres det, om man er kompetent? Der er ingen kodeks, man kan slå op i for at få sin kompetence bedømt. Kompetencer afprøves og udfoldes i interaktionen og viser sig i udfaldet. De er hverken overleverede eller fælles forudsatte, men tværtimod dannet af de erfaringer, vi hver især har gjort. Kompetence er dermed evnen til at anvende (og teste) kognitive modeller på konkrete situationer og afstemme adfærden, således at det er muligt at tilpasse både adfærden, situationsfornemmelsen og hypoteserne i forhold til interaktionens faktiske forløb. Herved opstår der en form for fælleshed i deltagernes handlinger, idet de relaterer sig til hinanden.

Vores handlinger udspringer af en praktisk viden om, hvordan verden er beskaffet, hvordan vores egen position i forhold til denne beskaffenhed er, hvordan vi følgelig kan opføre os kompetent i forhold til den situation, vi befinder os i, etc. Og omvendt: vores handlinger virker tilbage på denne praktiske viden. Idet vi bruger vores kompetencer bliver vi mere kompetente: dvs. mere erfarne og vidende om de situationer og relationer, som vi indgår i. Der er således tale om en vekselvirkning: handlingerne er begrundet i den abstraktion, som vi har benævnt en 'kognitiv model' eller en 'situationstype', og udbygger eller justerer samtidig denne model. En 
konsekvens af vekselvirkningen er, at der skabes en relation mellem 'indehavere' af private kognitive modeller.

\section{Situation og kode}

Evnen til at fremstå kompetent afhænger i særdeleshed af situationsfornemmelse: dvs. af evnen til at spille en overbevisende rolle i interaktionen. Tankstationen $\mathrm{fx}$ skal se kompetent ud i mulige kunders øjne. Det skal virke som et typisk sted, hvor man kan få fyldt tanken op. Ekspedienten skal ligeledes kunne besvare almindelige henvendelser fra kunderne. Kunden skal have en rimelig klar fornemmelse for, hvad det er muligt at bede om, hvis henvendelsen skal kunne tages alvorligt. Alt dette kræver kendskab til situationstypen fra de interagerendes side. Vi bør derfor se nærmere på, hvordan deltagernes viden om situationstypen er organiseret. I tråd med vores tilgang vil vi hævde, at denne organisering er tekstlig. Tekstligheden skyldes, at den kognitive model organiserer både semantiske kompetencer i form af leksikalsk viden om, hvad der tematisk set passer i situationen, og syntaktiske kompetencer som viden om, hvordan interaktionen ret beset bør forløbe.

Situationstypens semantik er i første instans paradigmatisk organiseret ved hjælp af en taksonomi af hierarkisk organiseret viden (van Dijk, 1985), som klassificerer de forskellige services, varer og/eller hændelser, som er mere eller mindre typiske for situationen. Herved fastlægges både pertinente træk og frie elementer ved situationen. For benzintanksituationens vedkommende er tilstedeværelsen af benzinprodukter og en række biltilbehør (billygter, tændrør, sprinklervæske etc.) pertinente træk. Disse træk udgør et paradigme af obligatoriske elementer, der skal være til rådighed - dvs. kunne købes - for, at der er tale om en tankstation. De er typificerende for situationen: fordi der kan købes benzin, diesel og andre olieprodukter til automobiler, er der tale om en tankstation. Vi har forventninger om, at vi kan købe disse ting her, fordi vi tidligere har gjort os erfaringer med lignende steder. Og endvidere forventer vi, at vi så også kan købe tændrør og andet tilbehør på stedet - og evt. at der er kyndigt råd om, hvordan tændrør skiftes. Forskellen på en benzinstander og en tankstation er netop, at assortimentet på det sidstnævnte sted er mere udbygget. Tankstationen er en benzinstander med mere.

De typificerende elementer er definerende men ikke udtømmende for situationen. Det er fx sandsynligt, at der findes både anlæg til bilvask og kundetoiletter på tankstationer. Hvis denne forventning skuffes, så holder stedet dog ikke op med at være en tankstation. Den er blot en 'dårlig' repræsentant af typen. Tankstationen er således ikke defineret som et pissoir med mere. De sandsynlige elementer er et paradigme af træk, der plejer at være til stede, men ikke behøver at være der. De vil (typisk) være der, uden at skulle være der. Dermed er taksonomien langt fra fuldstændig. Der er også et paradigme af mulige elementer: af træk, der kan være til stede, uden at de altid plejer at være det - fx visse rekreationsformer (spillemaskiner, græsplæne), forplejningstilbud (grillbar, automater), dagligvarer (kiosk, minimarked). Tilstedeværelsen af en eller flere elementer fra dette paradigme gør stationen til et udbygget eksemplar af typen: stedet bliver en tankstation med mere.

En fjerde kategori er de usandsynlige elementer: træk der ikke plejer at være tilstede, men godt til en vis grad kan være det, uden at situationen af den grund skal omdefineres grundlæggende - fx hvis der tillige sælges istandsatte cykler i butikken. Dette fjerde paradigme er kategorien mellem paradigmet af mulige elementer og et femte paradigme af umulige elementer: dvs. træk der er udelukket, fordi de er i modstrid med den grundlæggende definition af situationen. Denne definition er så i øvrigt betinget af paradigmet af obligatoriske elementer (i dette tilfælde: 
de varer der skal være tilstede - benzin- og andre autoprodukter) og den metakommunikative ramme (jf. Bateson, 1990) omkring interaktionen, der besvarer spørgsmålet: Hvad foregår der her? De umulige elementer udelukker således de obligatoriske elementer og er i modstrid med den overordnede ramme: køb og salg af varer og ydelser i privat virksomheds regi. Der er fx hverken tuskhandel, religiøs forkyndelse eller offentlig forvaltning på tankstationer.

Tankstationens situerede semantik er følgelig en taksonomi bestående af fem kategorier med hver sin modalitet. Det kan vises i følgende model:

\begin{tabular}{ccccc}
$\begin{array}{c}\text { obligatoriske } \\
\text { elementer }\end{array}$ & $\begin{array}{c}\text { sandsynlige } \\
\text { elementer }\end{array}$ & $\begin{array}{c}\text { mulige } \\
\text { elementer }\end{array}$ & $\begin{array}{c}\text { usandsynlige } \\
\text { elementer }\end{array}$ & $\begin{array}{c}\text { umulige } \\
\text { elementer }\end{array}$ \\
\hline $\begin{array}{c}\text { skal/bør være } \\
\text { præsent }\end{array}$ & $\begin{array}{c}\text { vil typisk være } \\
\text { præsent, men skal } \\
\text { ikke }\end{array}$ & kan være præsent & $\begin{array}{c}\text { vil typisk ikke være } \\
\text { præsent, men kan } \\
\text { være det }\end{array}$ & $\begin{array}{c}\text { skal/bør ikke } \\
\text { være præsent }\end{array}$ \\
\hline
\end{tabular}

De fem kategoriers modaliteter er for så vidt situationsuafhængige. Alle situationer er karakteriseret ved for det første at rumme såvel typificerende som andre elementer, og for det andet ved, at forskellen mellem disse elementer på et formelt plan skyldes modalitet. Det er derimod kontingent og følgelig situationsafhængig, hvilke indholdselementer, der bliver anset for at være obligatoriske for en bestemt situationstype, og hvilke elementer, der er mere eller mindre sandsynlige eller mulige. Vores forestillinger om situationen differentierer således mellem, hvad vi med sikkerhed forventer at finde i situationen, hvad der er sandsynligt eller muligt at finde og hvad der ville være overraskende eller udelukket at møde i situationen.

Det er endvidere foranderligt, hvilke indholdselementer der er obligatoriske, sandsynlige, mulige, usandsynlige eller umulige. Når indholdet i situationstypens modaliteter ændres, så afstemmer deltagerne deres adfærd i forhold til nye erfaringer og nye kompetencekrav. Kodeændringer sker således ikke på et 'makrokulturelt' niveau (i 'systemet'), men ved en kognitiv tilpasning i form af hypotesejustering hos den enkelte deltager. Disse kodeændringer og hypotesejusteringer sker uden større besvær, fordi den situerede semantik rummer en evolutionær dynamik for realiseringen af potentialer. Udviklingspotentialet er nemlig indeholdt i semantikkens mulige og usandsynlige (og til tider endda: hidtil umulige) elementer, der kan transformeres til obligatoriske, sandsynlige hhv. mulige elementer. Det er på den måde, tankstationssituationen i det forgangne århundrede har udviklet sig.

Semantikken er her blevet analyseret med henblik på den paradigmatiske ordning. Men det er klart, at paradigmatikken også på semantikkens niveau understøttes af stedets syntagmatik. Syntagmet fastlægger hierarkiet i de forskellige elementers vægt og aftegner dermed det forløb, som handlingen med fortrin kan eller bør følge på stedet (jf. Floch, 1990). For tankstationens vedkommende lader den visuelle og rumlige placering ingen tvivl om, at benzinstanderne er et væsentligt indholdselement. Men i modsætning til tidligere er benzinstanderne i dag overdækket og derved forbundet med hovedbygningen, som kunden skal bevæge sig hen til og ind i. Standerne er da heller ikke længere tankpasserens arbejdssted, men kundens domæne. Tankpasseren befinder sig inden for, og er i øvrigt ikke tankpasser længere, men ekspedient med en indsnævret kompetenceprofil. ${ }^{2}$ Inden for: det er også stedet, hvor ikkeautomobilgeneriske produkter sælges både til trafikanter og nabolaget. Disken er således blevet 
syntagmets andet dominerende element: der hvor regningen for selvbetjeningen (både ved standerne og i minimarkedet) betales og hvor kunden kan henvises til stedets evt. Nebengeschäfte: bilvaskautomaterne, solariet etc., som også syntagmatisk behandles som underordnede elementer.

For at kunne fremstå som en kompetent deltager i interaktionen skal tankstationen agere typisk repræsentant for arten 'tankstation'. Kendetegnene for denne art er frembragt af tidligere handlinger: af 'det, der er gjort'. Men som vi så, er specificeringen af arten en evolutionær proces på grund af det udviklingspotentiale, som er tilstede i artens semantik. Innovationer sker med henblik på at udmønte potentialet bedre eller anderledes. De efterfølgende interaktioner afgør ved selektion, om og i hvilken grad innovationerne vinder varigt indpas. I så fald er 'det overraskende' blevet 'selvfølgeligt'. Kendetegnene er på den måde dynamiske, og dynamikken hviler ikke på en kollektiv aftale, men på hvad enkelte aktører gør i forhold til situationen og af hvilken lære, de drager af deres erfaringer.

Der findes altså en semantisk kode, som får sit indhold fra de erfaringer, som aktører hver især har gjort sig i konkrete interaktioner. Det er på den måde, hver deltager opbygger sin egen situationsfornemmelse. Den enkelte aktørs erfaringer ligner mange andres, derfor vil situationsfornemmelsen langt hen ad vejen være afstemt med de øvrige deltagere, hvorved der opstår samklang.

\section{Situation og sekvens}

Vi vil nu vende blikket væk fra tankstationens 'deltagelse' i interaktionen og i stedet se på de andre deltageres bidrag for at analysere situationstypens syntaks. Syntaksen er selvfølgelig i første instans syntagmatisk kodet, idet den fastlægger det prototypiske forløb af interaktionen. Det er fremdeles syntaksen, der fastlægger valgmulighederne på bestemte tidspunkter i sekvensen. Derved har den også betydning for de interaktionsroller, deltagerne kan indtage.

Set fra kundens optik afhænger evnen til at gebærde sig kompetent på tankstationen af kendskab og kundskab i forhold til det storsyntagme, som besøget på stedet udgør. Storsyntagmet består af en række mindre episoder, der i sig selv er sekvenser og altså syntagmatisk organiserede: køen foran tanken, selvbetjeningen, indkøbet i minimarkedet, betalingen, andre forretninger (strække ben, tisse af), exit etc. Rækkefølgen mellem disse sekvenser har drejebogslignende karakter (jf. Schank og Abelson, 1977). Episoderne kommer fra to forskellige erfaringsregistre eller paradigmer: den ene er specifik for tankstationer og kan kun på en ganske abstrakt måde læres i eller overføres til andre situationer ( $f x$ selvbetjeningen ved standeren), den anden er gyldig for en hel række lignende købssituationer (fx ekspeditionssekvensen). De enkelte episoder er placeret mere eller mindre bundne i forhold til storsyntagmet: da der kan tisses af, både før kunden deltager i kødannelsen og efter ekspeditionen er afsluttet, er denne episode mindre bundet end exit, der altid afslutter sekvensen. Desuden er nogle episoder obligatoriske for storsyntagmet, mens andre er valgfrie. Der behøver ikke at være $k ø$, kunden er ikke forpligtet til at købe yderligere varer i minimarkedet eller til at tisse af: disse episoder er valgfrie. Omvendt skal der betales, for at der kan være tale om et køb, og uanset hvad skal sekvensen slutte: disse episoder er obligatoriske for købssituationer.

Besøget på tankstationen har således sin egen syntaks. Det, som gælder for situationen som helhed, gælder tillige for de enkelte episoder, der konstituerer den overordnede sekvens. Også de er bygget op af bundne og ubundne komponenter og af obligatoriske og valgfrie elementer. 
Det kan illustreres ved et eksempel på en ekspeditionssekvens, som jo i sig selv er en obligatorisk episode i købssituationer på tankstationer: ${ }^{3}$

\begin{tabular}{|c|c|c|}
\hline $\begin{array}{l}\text { SI } \\
\text { (Salgsindledning) }\end{array}$ & $\begin{array}{l}\text { Ekspedient } \\
\text { Kunde }\end{array}$ & $\begin{array}{l}\text { Hvis tur er det? } \\
\text { Det er vist min tur }\end{array}$ \\
\hline $\begin{array}{l}\mathrm{H} \\
\text { (Hilsen) }\end{array}$ & $\begin{array}{l}\text { Ekspedient } \\
\text { Kunde }\end{array}$ & $\begin{array}{l}\text { Hej } \\
\text { Hej }\end{array}$ \\
\hline $\begin{array}{l}\text { SF } \\
\text { (Salgsforespørgsel) }\end{array}$ & Kunde & $\begin{array}{l}\text { Jeg vil gerne have } 20 \text { Kings og Politiken } \\
\text { (lægger Politiken på disken) }\end{array}$ \\
\hline $\begin{array}{l}\text { SA } \\
\text { (Salgsaccept) }\end{array}$ & Ekspedient & $\begin{array}{l}\text { (Lægger } 20 \text { Kings på disken) Værsgo', var } \\
\text { der ellers andet? }\end{array}$ \\
\hline & Kunde & Nej tak, det var det hele \\
\hline $\begin{array}{l}\text { S } \\
\text { (Salg) }\end{array}$ & Ekspedient & Så bliver det $42 \mathrm{kr}$. \\
\hline $\begin{array}{l}\mathrm{K} \\
(\mathrm{K} ø \mathrm{~b})\end{array}$ & $\begin{array}{l}\text { Kunde } \\
\text { Ekspedient }\end{array}$ & $\begin{array}{l}\text { Her er } 100 \mathrm{kr} . \\
\text { Tak }\end{array}$ \\
\hline $\begin{array}{l}\text { KA } \\
\text { (Købsafrunding) }\end{array}$ & Ekspedient & Og der var 58 kr. retur, værsgo'. \\
\hline A & $\begin{array}{l}\text { Ekspedient } \\
\text { Kunde }\end{array}$ & $\begin{array}{l}\text { Ha' fortsat en god aften } \\
\text { I lige måde }\end{array}$ \\
\hline
\end{tabular}

De tre elementer, som er fremhævet i fed i kolonnen til venstre, er obligatoriske, for at interaktionen i det hele taget kan forløbe. Salgsaccepten, som drejer sig om ekspedientens mulighed for at indvillige eller afvise salg af en vare efter salgsforespørgslen, er til gengæld uundværlig, hvis ikke ekspedientens bidrag til interaktionen skal vurderes som uforskammet. ${ }^{4}$ Så dette element er uundværligt for opretholdelsen af relationen i situationen. Købsafrundingen, som foretages af ekspedienten, har ligeledes til formål at opretholde høfligheden i interaktionen og er derfor ligeledes uundværlig.

Disse fem elementer er desuden bundne i forhold til hinanden. De skal optræde i denne rækkefølge i interaktionen, så forløbsstrukturen for de obligatoriske elementer er $\mathrm{SF}^{\wedge} \mathrm{SA}^{\wedge} \mathrm{S}^{\wedge} \mathrm{K}^{\wedge} \mathrm{KA} .{ }^{5}$ De obligatoriske elementer og deres bundne rækkefølge er typificerende for situationen: dvs. når disse elementer er til stede i interaktionen, kan den genkendes som et tilfælde af situationstypen 'ekspedition'.

At et element er valgfrit, betyder omvendt, at det ikke er nødvendigt for, at interaktionen kan genkendes som ekspedition. Hverken salgsindledning (SI), hilsen (H) eller afsked (A) er typificerende for ekspeditioner, men de er alle tre bundne elementer enten i begyndelsen eller ved afslutningen af interaktionen. Hilsen og afsked er begge fatiske, idet de har til formål at bekræfte kontakten mellem de to interagerende (Jakobsen, 1960). Denne funktion bruges i et utal af situationer. Salgsindledningen handler om at regulere turtagning mellem kunder, så et salg kan indledes med næste kunde (Sacks m.fl., 1978). Dette element forekommer ikke kun i købssituationer, men også $\mathrm{i}$ andre institutionelle sammenhænge, hvor forholdet mellem 'kunder' skal reguleres: f.eks hos lægevagten eller på biblioteket. Elementet er derfor ikke genrespecifikt for den situationstype, som vi undersøger.

Ud over disse tre valgfrie elementer kan der også være elementer, som gentages. Disse gentagelser er ligeledes valgfrie i forhold til situationstypen, men de kan desuden gentages et vilkårligt antal gange efter SI-elementet. Og ydermere er de relativt ubundne. Kunden kan 
påbegynde en salgsundersøgelse (SU) på mange punkter i sekvensen (fx "Hvor meget tjære er der egentlig $i$ Kings?"). Ofte indledes salgsundersøgelsen (SU) med en implicit salgsforespørgsel (SF): "Jeg skal have nye pærer til mine forlygter". Det betyder, at de obligatoriske elementer SA (fx "Ok, var det ellers andet") og SF ("Ja, har i fxlgrens til alufxlge?") også er gentagelseselementer. De kan fremsættes et vilkårligt antal gange, indtil kunden ikke ønsker at købe flere varer og ekspedienten får negativ respons på sine invitationer til yderligere salgsforespørgsler fra kunden.

Tilsammen udgør de obligatoriske og valgfrie, de bundne og ubundne samt gentagelseselementerne situationstypen 'ekspedition', hvilket Halliday og Hasan (1985) kalder det "generiske strukturpotentiale" (GSP): dvs. koden for de realiseringsmuligheder, som arten (her: ekspeditionssituationen) strukturelt set har. Den formelle beskrivelse af ekspeditionssituationens GSP-kode er følgende: ${ }^{6}$

GSP: $\left.\left[(\mathrm{H}) \cdot(\mathrm{SI})^{\wedge}\right]\left[(\mathrm{SU} \cdot) \mathrm{SS}^{\wedge} \mathrm{SA}^{\wedge}\right\}^{\wedge} \mathrm{S}\right] \mathrm{K}^{\wedge} \mathrm{KA}\left({ }^{\wedge} \mathrm{A}\right)$

Det generiske strukturpotentiale viser ikke en konkret ekspeditionssituation, men angiver de strukturmuligheder, som gør, at et stort antal konkrete tilfælde kan realiseres og genkendes som tilhørende situationstypen eller genren 'ekspedition'. Netop den generiske struktur er årsagen til, at ekspeditioner i langt de fleste tilfælde har et gnidningsfrit forløb med et minimalt forbrug af opmærksomhed og energi. Vi kender den generiske struktur for denne situationstype til hudløshed og ved erfaringsmæssigt, hvordan vi kan variere den efter behov. Den er det selvfølgelige grundlag for interaktion: en situeret syntaks, som i den konkrete situation begrænser antallet af valgmuligheder fra det sproglige register og samtidig bekræfter, at deltagernes fornemmelse for og sproghandling i situationen er korrekt og adækvat.

I forlængelse af vores analyse af den situerede semantiks udviklingspotentiale kan vi sige, at også den situerede syntaks er historisk dannet, idet konkrete interaktioner har gjort visse valgfrie elementer obligatoriske og bundet rækkefølgen mellem bestemte elementer. Drivkraften i denne udvikling er 'økonomiprincippet': behovet for at kunne udføre ens eget bidrag til standardsituationer på en rutiniseret facon, dvs. så 'omkostningsfri' og ubesværet som muligt. Ligesom med tankstationens semantik er der på den måde blevet fastlagt en ny situationstype - 'ekspedition' -, der er lagret som et skema for adfærd og sprogbrug i bevidstheden: dvs. som en kognitiv model, der kan appliceres i fremtidige situationer af samme art. GSP-koden er hverken et medfødt instinkt eller en kollektiv vedtaget kodeks.

Men det betyder fremdeles, at nye interaktioner kan ændre ved forholdet mellem valgfrie og obligatoriske elementer samt ved rækkefølgen i det generiske strukturpotentiale. Det ser vi netop et eksempel på i vores egen tankstationsinteraktion, som har følgende realiserede syntaks:

\begin{tabular}{lll}
$\begin{array}{l}\mathrm{H} \\
(\text { Hilsen})\end{array}$ & $\begin{array}{l}\text { Ekspedient } \\
\text { Kunde }\end{array}$ & $\begin{array}{l}\text { Goddag Hr. } \\
\text { (Besvarer ikke hilsen) }\end{array}$ \\
\hline $\begin{array}{l}\text { SI } \\
\text { (Salgsindledning) }\end{array}$ & Ekspedient & Hvad kan jeg gøre for Dem? \\
\hline $\begin{array}{l}\text { SF } \\
\text { (Salgsforespørgsel) }\end{array}$ & Kunde & Jeg har tanket benzin på stander 5 \\
\hline S (Salg) & Ekspedient & Det bliver 354,75. \\
\hline
\end{tabular}




\begin{tabular}{lll} 
SA (Salgsaccept) & & Ellers andet? \\
\hline (...Udeladelse...) & & \\
\hline A & Ekspedient & De må fortsat have en god dag, Hr. \\
(Afsked) & Kunde & Tak \\
\hline
\end{tabular}

Følgende struktur er realiseret fra det generiske strukturpotentiale:

$\mathrm{H}^{\wedge} \mathrm{SI}^{\wedge} \mathrm{SF}_{1} \wedge \mathrm{S}^{\wedge} \mathrm{SA}_{1} \wedge$ (udeladelser: $\left.\mathrm{SF}_{2} \wedge \mathrm{SA}_{2} \wedge \mathrm{S}^{\wedge} \mathrm{K}^{\wedge} \mathrm{KA}\right)^{\wedge} \mathrm{A}$

Vores case indeholder de bundne, valgfrie elementer H, SI, A, hvis funktion er at skabe og vedligeholde den interpersonelle relation mellem ekspedient og kunde. Men desuden er strukturens potentiale realiseret på en måde, som ikke passer helt med Halliday og Hasans GSP-kode, idet S ("Det bliver 354,75") strukturelt fremsættes før SA ("Ellers andet?"). Hermed afviges der fra den bundne rækkefølge mellem disse to obligatoriske elementer. Ikke desto mindre fungerer interaktionen gnidningsfrit på dette punkt. En sådan videreudvikling er altså mulig, især når den - som her - fungerer som en 'økonomisk' variant af koden. Ved at fremsætte både S og SA i samme tur, giver ekspedienten kunden to valgmuligheder i interaktionen:

a. Hvis kunden ikke ønsker at købe flere varer, er prisen og hermed S-elementet fremsat, hvilket kræver, at kunden betaler $\mathrm{K}$.

b. Hvis kunden imidlertid ønsker at fremsætte yderligere SF for at købe flere varer, kan kunden betragte $S$ som en foreløbig eller 'subtotal' prisinformation.

Trods denne afvigelse fra GSP-koden forløber den sproglige interaktion problemløst. Det betyder, at varianter og mutationer i forhold til GSP kan accepteres, så længe de ikke rokker ved den overordnede definition af situationen og ved rollefordelingen mellem deltagerne.

Opsummerende kan vi sige, at en sekvens er et tidsbegrænset forløb, hvor begyndelse og afslutning som bundne obligatoriske elementer markerer interaktionens grænser og hvor en rækkefølge af bundne - men potentielt gentagelige - elementer inden for sekvensens afgrænsede tidsinterval typificerer situationens emne. Disse elementer er ligeledes uundværlige og anvendes af aktørerne for at nå deres respektive målsætninger med interaktionen: i dette tilfælde køb og salg af benzin og dagligvarer. Inden for situationens grænser og overordnede definition (formålet) kan sekvensen udbygges med valgfrie elementer, der enten uddyber begyndelsesafsnittet, afslutningsafsnittet eller det mellemspil, som er typificerende for situationen. Det vil samtidig sige, at de valgfrie elementer ikke er vilkårlige i forhold til situationen. Dels er de bundet til bestemte afsnit i sekvensen: en hilsen kan fx ikke fremsættes ved situationens afslutning. Dels skal de valgfrie elementer svare til situationstypen. De skal netop være uddybende i forhold til aktørernes formål i og med situationen. I modsat fald sker der en sammenblanding af situationstyper, som fx når kunden pludselig gør kur til ekspedienten.

Situationstypens syntagme sætter således rammerne for den faktiske interaktions afvikling. Syntagmet er et potentiale af elementer, hvoraf nogle skal anvendes, andre bør anvendes (høflighed) og andre atter kan anvendes, mens mange andre ytringer ikke må anvendes. Desuden fastlægger syntagmet den overordnede rækkefølge, som de mulige (valgfrie), uundværlige og obligatoriske ytringer bør anvendes i. Når interaktioner 'gøres', så sker det derfor ikke mindst 
med udgangspunkt i denne syntaks (GSP), som forlods er 'gjort'. De konkrete interaktioner realiserer syntagmets potentiale. De er erfaringsbaserede: fremvisning, udøvelse og opøvelse af kompetencer i forhold til et på forhånd afmærket potentiale.

Potentialet sætter deltagernes kompetencer $i$ og på spil. Hvis de skal optræde kompetente i interaktionen, må deltagerne udfolde sig inden for situationstypens rammer. 'Inden for rammerne' vil sige, at de skal vise, at de behersker situationstypens syntagmatik og paradigmatik. Og 'udfolde sig' betyder, at rammerne er vide, og tilsvarende at valgmulighederne på bestemte steder i det syntagmatiske forløb er mangfoldige. Den måde, hvorpå disse muligheder forvaltes, er derfor med til at specificere relationen mellem deltagerne og i særdeleshed den rolle, deltagerne ønsker at spille i forhold til hinanden.

Det er fremdeles et spørgsmål om de paradigmatiske valg, der foretages på baggrund af syntagmet. Derfor er det ikke nok at vide, at og hoor der kan siges en salgsindledende ytring: "Hvad siger du?". Man skal også vide, hvordan ytringen fremsiges kompetent - fx "Hvad kan jeg gøre for Dem?" - og hvilken konsekvens dette valg har. Det handler om konkrete sproglige valg, som har konsekvenser for realiseringen af forholdet mellem deltagerne. Det undersøges i næste afsnit.

\section{Situation og relation}

Ved at strukturere rækkefølgen i interaktionen fastlægger GSP-koden deltagernes position i forhold til hinanden. Strukturpotentialet angiver, hvor i sekvensen, aktørerne kan eller skal træde i karakter og udfylde deres specifikke rolle i interaktionen. Men måden, hvorpå interaktionsrollerne så rent faktisk forvaltes, beror på paradigmatik. Kompetencer vedrører altså syntaktisk viden om, hvad der skal siges hvor i forløbet, såvel som selektionsfærdigheder mht. hvorledes ytringen siges for at indfri intentionen med interaktionen. De paradigmatiske valg af specifikke ytringer på bestemte steder i sekvensen skaber således en interpersonel ramme omkring situationen, der for det første specificerer, hvordan deltagerne ser på hinandens position og på deres egen rolle i interaktionen, og derved for det andet realiserer en relation mellem deltagerne. I forlængelse af Morris' (1938) heuristik, der skelner mellem syntaktiske, semantiske og pragmatiske niveauer, er dette et spørgsmål om interaktionens pragmatik. Denne virkning frembringes altså i interaktionens realisering af situationstypens semantik og syntaks.

For at undersøge denne pragmatik nærmere, må vi se på sekvensens valgfrie elementer hilsen $(\mathrm{H})$, salgsindledning (SI) og afsked (A), der, som sagt, specificerer den interpersonelle relation mellem de interagerende. Vi ser på de personlige pronominer og de tiltaleformer, som anvendes $\mathrm{i}$ vores eksempel. Det er netop disse paradigmatiske valg i forhold til syntaksens potentiale, som specificerer deltagernes syn på egen og modpartens position og rolle i interaktionen.

Pronominer fastlægger referencen til personer for deltagerne i interaktionen. De identificerer personers tid og sted i forhold til kommunikationen. I en sætning som fx "Kom nu herhen $d u$ " kan kun de tilstedeværende identificere person, tid og sted entydigt. Disse personreferencer er i nogle sammenhænge bedre kendt under betegnelsen deiksis, herunder persondeiksis (Fillmore, 1971). I funktionel lingvistik anvendes et lignende begreb for deltagere $i$ den umiddelbare situationskontekst (Martin, 1992, p. 124; Martin og Rose, 2003, p. 171). En sådan reference kaldes

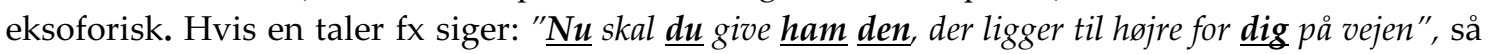
kræver det, at modtageren er til stede i samme tid og rum for at kunne udlede identiteten af referenterne fra den umiddelbare situationskontekst. Eksoforiske referencers funktion er at 
holde styr på og spore identiteter og objekter uden for teksten, så teksten hænger sammen og giver mening for den anden part i kommunikationen. Men det er ikke de personlige pronominers eneste funktion. Det kan vises ved at underkaste ekspedientens ytringer en simpel kommutationsprøve, hvor et betydningselements valør undersøges ved at udskifte dette element med et, der er paradigmatisk beslægtet:

\section{SI}

Hvad kan jeg gøre for Dem?(Eksempel)

Hvad kan jeg gøre for dig? (Kommutation)

$A$

De må fortsat have en god dag, Hr. (Eksempel)

$\mathrm{Du}$ må fortsat have en god dag, Hr. (Kommutation)

I disse ytringer anvender ekspedienten 2. person singularis i de eksoforiske referencer til kunden, men bruger henholdsvis 'du' og 'De' formen. De funktionelle betegnelser 'uformel' og 'formel' kan bruges til at karakterisere forskellen mellem disse to former. Valget af pronomen er i dette tilfælde en manifestation af ekspedientens holdning og forventning til den interpersonelle relation med kunden. I det øjeblik han har selekteret og ytret den formelle/høflige form, har han samtidig skabt og defineret relationen som 'formel' og 'høflig' med en betydelig social grad af distance. Havde ekspedienten valgt de mindre formelle personlige pronominer 'du/dig', ville han have skabt en højere grad af social nærhed i relationen til kunden.

Ekspedientens valg af tiltaleform har imidlertid også en signifikant relationsskabende effekt, da tiltaleformer kan anvendes til flere formål på samme tid. For det første kan tiltaleform anvendes til at markere deltagernes sociale position i et hierarki, fx 'direktør-underordnet'. For det andet kan formen anvendes til at markere graden af nærhed og distance - dvs. kontakten - mellem deltagerne. For det tredje kan tiltaleformer graduere høflighed/afslappethed/uhøflighed. For det fjerde kan de også markere afsenderens evaluering af modtageren, fx 'Kloge Åge, Smukke Sara'. Og for det femte kan den henvise til kommunikationsparternes historisk betingede intertekstuelle referenceramme, som kan være både offentlig kendt (fx 'Ørnen fra Herning') og privat ( $\mathrm{fx}$ 'Bondejyderen'). Sprogbrugere kan således foretage valg fra et større system af tiltaleformer.

I vores eksempel har kun ekspedienten valgt tiltaleform, nemlig i interaktionsforløbets begyndelse og afslutning, ved $\mathrm{H}$ og $\mathrm{A}$.

$\mathbf{H}$

Goddag $\mathbf{H r}$.

A

De må fortsat have en god dag, $\mathrm{Hr}$.

At relationen mellem kunde og ekspedient er anonym viser sig ved valget af tiltaleformen 'Hr.', der kun markerer det for ekspedienten umiddelbart iagttagelige ved kunden. Hvis ekspedienten havde kendt kundens identitet, så kunne tiltaleformen være blevet udbygget ved at kombinere flere navnebaserede elementer: $\mathrm{fx}$ 'Hr. + (titel +) efternavn'. Og hvis ekspedient og kunde havde haft en mere nær relation, så kunne ekspedienten have valgt andre tiltaleformer 
end de formelt navnebaserede.

At ekspedienten ydermere specificerer relationen som formel, viser sig ved, at tiltaleformen ret beset kunne være helt udeladt, fx:

$\mathbf{H}$

\section{Goddag}

A

De må fortsat have en god dag

Den alternative afskedsytring demonstrerer endvidere, at 'Hr.' er redundant i forhold til den formelle form for 2. person singularis, 'De'. 'Hr.' tilføjer ingen ny information, men understreger til gengæld, at den høflige tone er oprigtigt ment. Der er således kohærens i valget af pronomen og tiltaleform.

Kohærensen bekræftes yderligere af valget af hilseudtryk, da 'goddag' er et mere neutralt og formelt ordvalg, sammenlignet med alternativer som 'hej', 'hejsa', 'dav', 'davs'. Dette valg optræder i let varieret form både i sekvensens start og slut. En redundans, som gør ekspedientens gestaltning af sin rolle til en sluttet helhed. Han fastholder fra begyndelse til ende et konsistent stilleje, som udtrykker en professionel kompetence i situationen: en evne til at præge interaktionen og definere relationen som 'formel' og 'høflig' med betydelig grad af social distance. At ekspedienten tager første taletur, viser fremdeles hans vilje til at sætte dagsordenen for interaktionen.

Ekspedientens indsats skaber således en metakommunikativ ramme omkring den interpersonelle relation (Bateson, 1990). Rammen viser, at relationen er upersonlig (anonym), men ikke af den grund ligegyldig - set fra ekspedientens side. Valget af pronomen og tiltaleform er nemlig fravalg af jovialitet og nonchalance, af ligeværdig kammeratskab såvel som sjusket desinteresse. Der markeres, at vi ikke er lige: at relationen altså er asymmetrisk. Denne asymmetri forvaltes imidlertid professionelt: herren skal have, hvad herren tilkommer. Indsatsen verbaliserer således på den ene side ekspedientens sociale underordning i forhold til kunden. Men ved at indsatsen sker professionelt - med direkte reference til den sociale asymmetri, hvor nogle bør tiltale andre i høflighedsformer - indstiftes der en ny form for gensidighed. Modparten (kunden) forventes at udvise samme respekt, som ekspedienten giver ham. Hvis denne respekt forstås som en gave, så bør kunden gengælde den for ikke at miste anseelse (jf. Mauss, 1990). På den måde sættes kunden i en reciprok relation til ekspedienten som potentiel underhund i en symbolsk (a)symmetri, hvor 'andre' bør gengælde 'nogles' tiltale symmetrisk, og bør gøre dette på en 'passende' måde, for at der ikke skal være tale om asymmetri.

\section{Relation og konflikt}

Det raffinerede ved ekspedientens udfyldning af interaktionsrollerne er fremdeles, at det metakommunikative budskab ikke fremsættes eksplicit. Ekspedienten indleder ikke samtalen med et 'Skal vi være De's?'. I stedet præsupponerer han relationen, uden at den skal gøres til genstand for diskussion eller forhandling. Med et af Goffmans begreber, så skaber ekspedienten en bestemt 'footing' (Goffman, 1995), en ramme for situationen. Et brud på 'footing' ville øge risikoen for, at en af parterne taber ansigt (Goffman, 1967). 
Kunden kan reagere på ekspedientens 'footing' ved at vælge tre forskellige typer tiltaleformer og personlige pronominer. Han kan vælge at benytte:

a. samme pronominer og tiltaleformer som ekspedienten: ' $\mathrm{De}$, ' $\mathrm{Hr}$.'

b. forskellige pronominer, ingen (evt. forskellige) tiltaleformer: ' $\mathrm{Du}$ ', ---

c. udelade pronominer og tiltaleformer: ---, ---

Hvis kunden vælger at anvende samme tiltaleformer og pronominer som ekspedienten, vil kommunikationen måske bedre kunne forløbe gnidningsfrit under ekspeditionen. Kunden accepterer ekspedientens 'footing', ingen af parterne risikerer at tabe ansigt. Set fra kundens perspektiv kan omkostningen dog være, at han skal gøre vold mod sin selvforståelse og sine idealer om 'uformelle', 'afslappede' omgangsformer også i professionelle situationer. I stedet skal han i den symbolske reciprocitets navn underkaste sig en formel omgangsform. Hvis det er tilfældet, sker kommunikationen godt nok gnidningsfrit men ikke automatisk.

Hvis kunden vælger mulighed to og afviser ekspedientens 'footing', gøres enten den sociale eller den symbolske asymmetri eksplicit. I første fald bekræfter kunden, at der er forskel på folk og at dette hierarki gerne må udtrykkes $\mathrm{i}$ et forskelligt valg fra tiltaleformernes og pronominernes paradigmer. Denne holdning ville dog være helt ude af trit med samfundsudviklingen i de seneste halvtreds år. Kunden ville kunne risikere at blive skammet ud af andre kunder på tanken - et ansigtstab. I andet fald kunne den videre afvikling af købshandlingen komme i fare. Kunde og ekspedient bliver nødt til at forholde sig til hinandens holdninger og eventuelt forhandle en fælles forståelse på plads for at få rettet op på truslen om ansigtstab. Interaktionen afvikles hverken gnidningsfrit eller automatisk.

Hvis kunden vælger at undgå at anvende tiltaleformer og pronominel reference til ekspedienten, så sikrer det, at ekspeditionen foregår gnidningsfrit. Der er ingen risiko for ansigtstab, og samtidig undgår kunden at skulle underlægge sig det formelle sprogbrug, som ekspedienten benytter sig af. Ulempen er dog, at eftersom der ikke er gensidighed, så er der heller ikke nogen interpersonel kontakt mellem deltagerne. Relationen mærkes af, at den sociale asymmetri forbliver symbolsk umedieret.

Vi kan sammenfatte disse konsekvenser i følgende skema:

\begin{tabular}{llll} 
& accept & ansigtstrussel & reciprocitet \\
\hline a. lighed & + & - & + \\
\hline b. forskel & - & + & - \\
\hline c. undvigelse & (unddragelse) & - & - \\
\hline
\end{tabular}

Hvis vi ser på vores konkrete interaktion, så er det klart, at kunden valgte den tredje mulighed:

$\mathbf{H}$

Ekspedient: Goddag Hr.

Kunde: (Besvarer ikke hilsen)

SF

Kunde: Jeg har tanket benzin på stander 5

A 
Ekspedient: De må fortsat have en god dag, $\mathrm{Hr}$.

Kunde: Tak

Ved at undgå tiltaleformer eller brug af personlige pronominer om modparten gør kunden sit bidrag til etableringen af relationen så neutralt som muligt. Symptomatisk for denne taktik er endvidere, at kunden enten ikke besvarer ekspedientens hilseudtryk (i $\mathrm{H}$ ) eller afstår fra at gengælde den (i A): 'Tak' vælges i stedet for fx 'I lige måde'.

Det raffinerede ved kundens taktik er, at markeringen af den talendes syn på relationen er så udvisket eller underspillet, at den anden deltager formodentlig end ikke opdager, at kunden ikke gengælder - og dermed faktisk forkaster - den ramme eller 'footing', som ekspedienten har foreslået. Derfor afvikles ekspeditionen gnidningsfrit. Men dermed er ikke sagt, at interaktionen så også er gnidningsfri for kunden. Kunden vælger en taktik, hvorved han undgår at handle i modstrid med sin egen opfattelse af, hvordan relationen burde være gestaltet: nemlig at også professionelle interaktioner ideelt set burde være 'uformelle'. Altså vælges der ikke at gengælde ekspedientens udspil med en reciprok replik (alternativ a.). Dette ville nemlig ud fra kundens idealer have været en 'tilpasningstaktik'. For at undgå at udsætte ekspedienten for en ansigtstrussel og undvige en eventuel konflikt afstår kunden endvidere fra at vælge 'konfrontationstaktikken' (alternativ b.). I stedet bruger kunden sin erfaring med GSPkoden og sin viden om sprogsystemets valgmuligheder til at vælge en kurs, som hverken er i modstrid med kundens syn på, hvordan interaktionen burde forløbe, eller - omvendt missionerer for dette syn. Men denne konfliktundvigende kurs kræver en kognitiv proces med refleksion over og tolkning af konsekvenserne af de sproglige valg, der kan træffes. Den er i den forstand 'uøkonomisk' og mangler - som konsekvens - den reciprocitet, som ekspedientens valg af 'footing' lagde op til.

Vi ser altså, hvordan den ene deltager afstemmer sin adfærd i forhold til den anden. Men i dette tilfælde opstår der hverken samklang eller dissonans. Hvis han vil undgå konflikt og ansigtstrussel (alternativ b.), må kunden enten spille en påduttet høflig rolle (alternativ a.) eller blive konfronteret med sin egen situationelle uhøflighed, da han ikke følger op på ekspedientens udspil (alternativ c.). Hans faktiske valg er således et valg mellem flere onder, hvor det forhold, at han netop beslutter sig for den undvigende - men også relationsudviskende - version, med al tydelighed viser, at hans beslutning bunder i et dilemma.

Vores case er således et eksempel på en interaktion, hvor egentlig intet sker, men som ikke desto mindre huskes. Da begge parter når deres mål med situationen (køb/salg) i forløbet, og da intet ændrer deres hensigter eller øger deres indsigt i situationen, så sker der egentlig intet. Men mens ingenting er i gang med at ske, så hænder der alligevel noget, som den ene part bagefter husker. Set fra kundens vinkel, rokkes der ved relationens automatisme: ved den metakommunikative ramme, som ellers plejer at specificere deltagernes position i forhold til hinanden (jf. Harré og van Langenhove, 1999). Der sættes spørgsmålstegn ved deltagernes rettigheder og forpligtelser i interaktionen, hvorved selve relationen bliver sat til diskussion eller endda på spil.

Der gøres. Og det der gøres, tiltrækker sig opmærksomhed og bliver husket, fordi det afviger fra, hvad der tidligere er gjort - og dermed fra hvad kunden forventede sig af situationen. Disse forventninger baserer sig nemlig på det gjorte, som er lagret som erfaring med denne og tilsvarende situationstyper, og har dannet et kognitivt beredskab til at handle på en bestemt måde i situationen. I vores case udfordrer interaktionen m.a.o. kundens situationsfornemmelse 
og i særdeleshed det aspekt, der vedrører gestaltningen af interpersonelle relationer.

Denne gøren kan analyseres ud fra vores model af den situerede semantik. Kundens forventninger til relationsdannelsen er nemlig begrundet $i$ en fornemmelse for, hvordan ekspedienten vil spille sin rolle som kompetent deltager. Det er et spørgsmål om erfaringer med paradigmatiske valg. Hvis han derfor ikke forlods ved, at ekspedientens sproglige valg er obligatoriske, så bygger kundens situationsberedskab på en skelnen mellem sandsynlige/mulige realiseringer, usandsynlige realiseringer og umulige realiseringer af ekspedientens valgmuligheder. Disse optioner kan vises i følgende model:

\begin{tabular}{lllll} 
& $\begin{array}{l}\text { obligatoriske } \\
\text { valg }\end{array}$ & $\begin{array}{l}\text { sandsynlige/mulige } \\
\text { valg }\end{array}$ & $\begin{array}{l}\text { usandsynlige } \\
\text { valg }\end{array}$ & umulige valg \\
\hline $\begin{array}{l}\text { kundens } \\
\text { forventninger }\end{array}$ & --- & 'Du' & & \\
eller ingen markering & ${ }^{\prime} e^{\prime}, \mathrm{Hr}^{\prime}$. & (ukvemsord) \\
\hline
\end{tabular}

Forventningen til de sandsynlige/mulige valg bygger både på kundens erfaringer med lignende situationer og på kundens ideal for, hvordan en 'uformel' og 'afslappet' relation bør 'gøres'.7 I den henseende vil både det usandsynlige og det umulige valg være uønskede valg, da de forstyrrer idealet.

I vores tilfælde har vi imidlertid et brud mellem den forventede realisering af ekspedientens rolle og ekspedientens faktiske realisering, som kunden - fordi denne realisering var usandsynlig og uønsket - ikke er forberedt på. Kunden må overveje med sig selv, hvorfor modparten har truffet det usandsynlige valg, og hvordan han selv kan forholde sig kompetent til dette uønskede udspil. ${ }^{\text {I }}$ I stedet for en interaktion per automatpilot får vi derfor en situation, som let kan udvikle sig til en dyst om positioner med ansigtstab (for ekspedienten) eller en oplevet utilstrækkelighed i situationen (for kunden) som det mulige udfald.

Hvis kundens hensigt med relationen var, at interaktionen skulle bygge på en konfliktfri gensidighed, så er han fra starten bragt i en catch 22 lignende situation, som han ikke kan vinde. Gengælder han ekspedientens udspil på en gensidig måde ved at bruge høflige tiltaleformer (reciprocitet, symmetri), så undgår han en åben konflikt, men kommer i konflikt med sit eget ideal: ideal og realitet bliver asymmetriske. Holder han fast i sit ideal, risikerer han derimod enten en åben konflikt (konfrontationstaktikken) eller at fremtræde uhøflig (den konfliktundvigende taktik). Begge løsninger skaber symbolsk set asymmetriske relationer. Dilemmaet kan vises i følgende skema, hvor (+) viser en potentiel konfliktsituation:

\begin{tabular}{llll} 
& tilpasning & konfrontation & undvigelse \\
\hline asymmetri* & - & + & + \\
\hline åben konflikt** & - & + & - \\
\hline indre konflikt*** & + & - & - \\
\hline
\end{tabular}

* asymmetri: manglende reciprocitet

** åben konflikt: en konfrontation mellem deltagernes bidrag til interaktionen

*** indre konflikt: en modsætning mellem idealet om 'ligeværdighed' og den manglende virkeliggørelse af idealet i interaktionen

Kundens erindring af situationen skyldes således oplevelsen af den indbyggede konflikt i interaktionen, idet han ikke kunne undgå enten at give afkald på egne idealer (tilpasning), 
skabe en konfrontation med ekspedienten eller komme til at virke uhøflig (undvigelse). Det er oplevelsen af "selv-diskrepans", der rodfæster sig (Higgins, 1987). Selv-diskrepansen mindsker deltagerens evne til at opnå den ønskede gyldighed i interaktionen (jf. prægnansprincippet). Der er for stor afstand mellem det "aktuelle", det "ideelle" og det "normative" selv: mellem det, kunden faktisk formår i situationen, det mål, han gerne ville nå i interaktionen (nemlig at være i kontrol med situationen), og den adfærd, kunden burde udvise (nemlig høflighed, gensidighed). Denne diskrepans opleves som ubehagelig i den konkrete situation.

Erindringen skyldes desuden, at det sproglige træk fra ekspedientens side, som kunden forlods antog var usandsynligt, fremover må betragtes som et muligt eller sandsynligt valg. Vi ser her et konkret eksempel på hypotesejustering. Situationen får derfor som konsekvens, at kunden efterlods må lave en revurdering. Hvis ikke han vil undgå stedet fremover, så må han:

- justere sine idealer, hvorved han 'bearbejder' den indre konflikt

- eller udvikle sine sproglige og nonverbale mønstre, så han er bedre garderet i tilsvarende situationer, og kan undvige reciprociteten uden at virke uhøflig

- eller udvide sin forståelse for ekspedientens adfærd, så den kan forklares plausibelt (for evt. at kunne 'bearbejde' ekspedienten bedre).

Revisionsarbejdet udvider eller ændrer kundens (selv-)indsigt og handlingsmønstre. Det giver nye kompetencer eller justerer selvbilledet. Denne 'gøren' er kultur.

\section{"Ellers andet?"}

Vores hverdagshandlinger er situationsbestemte. Vi afstemmer vores forventninger og optræden ud fra tidligere erfaringer og de forestillinger, vi har om os selv og de øvrige deltagere. Erfaringer og forestillinger er noget vi har med til interaktionen i form af mentale modeller og scripts, der danner en automatiseret baggrund for, hvad vi kan og vil i situationen, og som økonomiserer vort bidrag til interaktionen. Vi behøver ikke at overveje hvert træk. Det hænder dog, at situationen udvikler sig i en retning, så vi bliver nødt til at revurdere vores intentioner - og i yderste konsekvens: vores selvbillede. Vi har ikke helt den gennemslagskraft, som vi forlods antog. Kultur er i den henseende den konsekvens, som justerede forestillinger og forventninger har for fremtidige handlinger: altså den erfarings- og identitetsdannelse, som oplevelser i konkrete situationer foranlediger.

Kultur omsætter oplevelser til erfaring. Derved kan konkrete hændelser blive nye elementer enten i den implicitte erindring, som når vores automatiserede vaner - de adfærdsmønstre, der nærmest ligger på rygraden - justeres, eller i den autobiografiske hukommelse. Denne form for eksplicit erindring knytter det oplevede sammen med vores selvfortælling, hvorved selvbilledet - altså identiteten - potentielt ændres. Kultur er således den læring, der sker, idet vi i situationen oplever en fysiologisk ændring, en emotionel respons eller et brud på vores kognitive forventninger og dispositioner. Læringen gør, at kropsligt funderede oplevelser, som er situationsbundne og som sådan momentane og flygtige, får større erfarings- og identitetsmæssig permanens. I og med at hændelsen 'kultiveres', har vi den med til næste møde - som nye kompetencer, nye intentioner. Kultur tilføjer et refleksivt niveau til oplevelsernes biologiske plan, hvilket gør, at hændelserne bearbejdes med sigte på fremtidige handlinger (jf. Jantzen og Vetner, 2007a, 2007b)

I det eksempel, vi har analyseret, fører interaktionen til, at kunden må bearbejde nogle af sine kompetencer for at sikre sig, at lignende situationer ikke fremover giver tilsvarende dårlige 
oplevelser. Det var hverken kundens evner i forhold til interaktionens syntaktiske kode (nemlig den specifikke GSP-kode) eller situationens semantiske kode (situationstypen 'tankstation'), der voldte problemer. Det var derimod den pragmatiske kode, som knyttede sig til forventningerne til relationen, som uventet viste sig at være en udfordring. Ekspedientens tiltale brød med kundens forestillinger om en anonym, men uformel og udistanceret relation. Ekspedienten positionerede sig som 'tjener' overfor kunden, og relationen blev derfor metakommunikativt defineret anderledes, end 'herren' havde ønsket sig. Kunden blev sat i en respektfuld distance til ekspedienten, hvorved det præsupponeredes, at 'herren' gengjaldt 'tjenerens' sproglige træk. Kundens dårlige oplevelse blev fremkaldt af dette forventningsbrud og viste sig som en negativ emotionel respons, som kunden forsøgte at tackle ved undvigelse frem for konfrontation. Konsekvensen af episoden bliver, at kunden må genoverveje, hvem han er i forhold til ikke kun den konkrete ekspedient, men måske salgspersonale i almindelighed - altså et identitetsarbejde, der skal få det aktuelle, ideelle og normative selv til at stemme bedre overens. Desuden må han tage sin strategi i denne slags interaktioner op til revision. Han må kompetenceudvikle sig.

Dette arbejde finder sted på det tekstlige plan. Det er i tekster, i sproglige og andre betydningsdannende mønstre, at situationer konkretiseres og relationer konstitueres. I vores eksempel betyder den faktiske interaktion, at kunden må redefinere sin egen position $\mathrm{i}$ relationen. Dette skift medfører, at selve konteksten for interaktionen - nemlig situationen - må genovervejes. Hvad handler interaktionen i grunden om? Den drejer sig ikke længere 'blot' om køb af benzin og dagligvarer på en tankstation, men mindst lige så meget om sociale og symbolske magtrelationer, hvilket gør indfrielsen af kundens oprindelige intention med interaktionen alt andet end ubesværet. Den faktiske interaktion er derfor mere end en simpel realisering af de muligheder, som den abstrakte situationstype 'tankstation' rummer.

Konteksten bliver til $i$ teksten. Det er interaktionens forløb, som materialiserer, hvad det er, vi taler om (situationen), og hvordan vi så er i forhold til hinanden (relationen og dens positioner). Interaktionens deltagere afstemmer og forhandler således løbende det sagsforhold, som udvekslingen drejer sig om, og den form for kontakt, de hver især ønsker, der skal være mellem dem. Dette er meddelelsens referentielle og fatiske funktioner, som er konstitutive for meddelelsens kontekst. Disse funktioner realiseres gnidningsfrit, så længe parterne er enige om kommunikationens metasproglige funktion: altså om interaktionens koder. Hvis denne enighed trues eller ophører, kommer konteksten til forhandling. Eller rettere: så bøjes opmærksomheden væk fra interaktionens kontekst (sagsforholdet og kontakten) og ind mod meddelelsen selv. Det tekstlige aspekt ved selve interaktionen, som i hverdagen tjener til at indfri tekst-eksterne formål - nemlig at skabe kontakt, at udtrykke sig selv, at påvirke sin modpart eller at henvise til en sag -, kommer i fokus. Denne refleksivitet kaldes den poetiske funktion (Jakobson, 1960), og når den er i højsædet, så dekontekstualiseres meddelelsen. Meddelelsen kommer til at dreje sig om sig selv: om hvorledes ting kan eller bør siges og gøres, frem for om hoad eller for hvem der siges eller gøres. I vores eksempel kommer kundens bidrag til interaktionen til at handle om, hvordan relationen kan forvaltes mest hensigtsmæssigt, og ikke så meget om køb af benzin og cigaretter.

Enhver dekontekstualisering medfører rekontekstualisering: dvs. skabelsen af en ny forstålsesramme for, hvad meddelelsen handler om (Bauman og Briggs, 1990). I vores case rekontekstualiseres meddelelsen som et anliggende, der vedrører relationsdannelse og kodekompetencer. Den sproglige udveksling gør de positionsforskelle, som er konstitutive for almindelige købsinteraktioner, eksplicitte og endog emotionelt og kognitiv påtrængende - som ubehag. De vaner og forventninger, som til dagligt tages for givet, de-automatiseres. De bliver 
'gjort fremmede', kan på ny opleves i deres sanselige umiddelbarhed (nemlig som ubehag) og bliver som sådan erkendbare i deres (u)hensigtsmæssighed. Netop denne erkendelsesskabende effekt af fremmedgørelse (russisk ostranenie) er ifølge Sklovskij (1969), en af grundlæggerne af den formalistiske tekstteori, den poetiske funktions primære kvalitet. Men idet poetik rejser tvivl omkring det givnes berettigelse, er den uøkonomisk. Kultur er i den henseende den proces, som skal reintegrere den ny erkendelse med de eksisterende erfaringer. Den er - kunne man måske lidt overfrisk sige - vejviseren til "zonen for nærmeste udvikling" (Vygotsky, 1978).

Kultur er andet end læring slet og ret. Kultur hænder, når læring sker poetisk. Den hænder som en tekstlig praksis, en 'gøren', der er centreret om at gøre tekstlig praksis mest hensigtsmæssig, $f x$ at få en bedre sans for situationen eller en større prægnans i relationen. Kultur 'gøres' og 'gør', når teksten domineres af den poetiske funktion (Jakobson, 1971). Teksten bliver så en opøvelse i situationsfornemmelse med sigte på, at aktøren fremover kan realisere potentialet i faktiske situationer så økonomisk som muligt. Den bliver endvidere en identitetsbearbejdning med henblik på at sikre aktøren optimal prægnans i faktiske relationer. Kultur er således transformativ og skabende. Den gør noget nyt i forhold til det, der tidligere er gjort - nemlig: erfaringen. Dette nye gøres med henblik på kommende situationsbetingede praksisser: på dannelsen af nye automatismer.

Dette indebærer fremdeles, at kultur er refleksiv, aktørbaseret og performativ (jf. Jantzen, 1992, 2005; Sørensen m.fl., 2008). Den er performativ, fordi den udstiller de tekstlige forudsætninger for social interaktion og højner bevidstheden om de poetiske virkemidler, der indgår $\mathrm{i}$ dannelsen af 'fælleshed'. Den er aktørbaseret, for det første fordi den udspringer af de bidrag, som deltagere leverer til interaktionen og som ændrer noget ved forløbet i forhold til tidligere erfaringer med lignende situationer. For det andet, så vedrører kultur aktørens nye erkendelser af situationen og af sine egne muligheder i interaktionen. Den er refleksiv, fordi den udspringer af den poetiske funktions rekontekstualisering af meddelelsens betydning og fordi den foranlediger aktører til at anvende sådanne de-automatiseringer til at overveje etablerede rutiner og det eksisterende selvbillede.

Det pragmatiske kulturbegreb er, i modsætning til mere traditionelle forståelser af begrebet, ikke "det hele" eller nærmest alt (jf. Tyler, 1873; Williams, 1958). Det er nærmere næsten intet. Men dette intet er dynamisk, fordi det medierer mellem handlingers sociale og mentale univers. Det ændrer vores måde at handle og at forstå os selv og andre på.

\section{Referencer}

Bateson, G. (1990). A theory of play and fantasy. In G. Bateson, Steps to an Ecology of the Mind (pp. 150-166). New York: Ballantine.

Bauman, R. and C.L. Briggs (1990). Poetics and performance as critical perspectives on language and social life. Annual Review of Anthropology, 19: 59-88.

Berger, P.L. and T. Luckmann (1966). The Social Construction of Reality. A Treatise in the Sociology of Knowledge. Garden City, N.Y.: Anchor Books.

Bourdieu, P. (1990). The Logic of Practice. Oxford: Polity Press.

Brinkmann, S. (2008). Culture as practices. A pragmatist conception. Journal of Theoretical \& 
Philosophical Psychology, 28: 192-212.

Buford Juncker, H. (1960): Field Work: An Introduction to the Social Sciences. Chicago: University of Chicago Press.

Chomsky, N. (1966). Cartesian Linguistics: A Chapter in the History of Rationalist Thought. New York: Harper \& Row.

Dewey, J. (1922). Human Nature and Conduct. New York: Henry Holt.

Dijk, T. van (1985). Cognitive situation models in discourse production. The expression of ethnic situation models in prejudiced stories. In J.P. Forgas, (Ed.), Language and Social Situations (pp. 61-79). New York: Springer.

Dijk, T. van (2009). Society and Discourse. How Social Contexts Influence Text and Talk. Cambridge: Cambridge University Press.

Fairclough, N. (1995). Critical Discourse Analysis: The Critical Study of Language. London: Longman.

Fillmore, C.J. (1971). Santa Cruz Lectures on Deixis. Berkeley: University of California.

Floch, J.-M. (1990). The contribution of structural semiotics to the design of a hypermarket. International Journal of Research in Marketing, Vol. 4: 233-252.

Frimann, S. (2004). Kommunikation - tekst i kontekst: Tekstanalyse med Systemisk Funktionel Lingvistik. Aalborg: Aalborg Universitetsforlag.

Garfinkel, H, (1967). Studies in Ethnomethodology. Englewood Cliffs, N.J.: Prentice-Hall.

Goffman, E. (1959). The Presentation of Self in Everyday Life. New York: Doubleday.

Goffman, E. (1967). On face-work. An analysis of ritual elements in social interaction. In E. Goffman, Interaction Ritual. Essays in Face-to-Face Behavior. Chicago: Aldine.

Goffman, E. (1995). Forms of Talk. Philadelphia: University of Pennsylvania Press.

Grice, H. P. (1975). Logic and Conversation. In P. Cole and J.L. Morgan (Eds.), Syntax and Semantics, Vol. III: Speech Acts (pp. 41-58). New York: Academic Press.

Halliday, M.A.K. and C.M.I.M. Matthiessen (1999). Construing Experience Through Meaning: A Language-Based Approach to Cognition. London, New York: Cassell.

Harré, R. and L. van Langenhove (Eds.) (1999). Positioning Theory: Moral Contexts of Intentional Actions. Oxford: Blackwell.

Halliday, M.A.K and R. Hasan (1985). Language, Context, and Text: Aspects of Language in a Social-Semiotic Perspective. Geelong: Deakin University Press. 
Hasan, R. (1996). Ways of Saying: Ways of Meaning. Selected Papers of Ruquia Hasan. London: Cassell (Open Linguistic Series).

Heritage, J. (1984). Garfinkel and Ethnomethodology. Oxford: Polity.

Higgins, E.T. (1987). Self-Discrepancy. A theory relating self and affect. Psychological Review, 94: 319-340.

Hymes, D. (1974). Foundations in Sociolinguistics: An Ethnographic Approach. Philadelphia: Pennsylvania University Press.

Jakobson, R. (1956). Two aspects of language and two types of aphasic disturbances. In R. Jakobson and M. Halle (Eds.), Fundamentals of Language (pp. 69-96). The Hague: Mouton.

Jakobson, R. (1960). Closing statements: Linguistics and Poetics. In T.A. Sebeok (Ed.), Style in Language (pp. 350-377). Cambridge, Mass: MIT Press.

Jakobson, R. (1971). The Dominant. In L. Mateijka and K. Pomorska (Eds.), Readings in Russian Poetics: Formalist and Structuralist Views (pp. 82-87). Cambridge, Mass.: MIT Press.

Jantzen, C. (1992). Kulturanalysens (u)mulighed. Kultur \& Klasse, 71: 117-140.

Jantzen, C. (2005). Tertium datur: Kampen om kulturbegrebet. In A.S. Sørensens and K.K. Povlsen (Eds.), Kulturkamp og kulturkritik (pp. 85-103). Århus: Klim.

Jantzen, C. and M. Vetner (2007a). Design for en affektiv økonomi. In C. Jantzen and T.A. Rasmussen (Eds.), Oplevelsesøkonomi: Vinkler på forbrug (pp. 201-218). Aalborg: Aalborg Universitetsforlag.

Jantzen, C. and M. Vetner (2007b). Oplevelsens psykologiske struktur. In J.O. Bærenholdt and J. Sundbo (Eds.), Oplevelsesøkonomi: Produktion, forbrug og kultur (pp. 27-50). København: Samfundslitteratur.

Jensen, J.F. (1989). Det dobbelte kulturbegreb - den dobbelte bevidsthed. In H. Hauge and H. Horstbøll (Eds.), Kulturbegrebets kulturhistorie. Århus: Aarhus Universitetsforlag.

Johnson-Laird, P.N. (1983). Mental Models. Towards a Cognitive Science of Language, Inference, and Consciousness. Cambridge: Cambridge University Press.

Kruuse, E. (1999): Kvalitative forskningsmetoder i psykologi og beslægtede fag. København: Dansk Psykologisk Forlag.

Lave, J. and E. Wenger (2003). Situeret læring - og andre tekster. København: Hans Reitzel.

Martin, J. R (1992). English Text: System and Structure. Amsterdam: Benjamins.

Martin, J. R. and D. Rose (2003). Working with Discourse: Meaning Beyond the Clause. London, New York: Continuum. 
Mauss, M. (1990). The Gift. The Form and Reason of Exchange in Archaic Societies, London: Routledge.

Morris, C. (1938). Foundations of the Theory of Signs. Chicago: Chicago University Press.

Sacks, H., E.A. Schegloff and G. Jefferson (1978). A simplest systematics for the organization of turn taking for conversation. In J. Schenkein (Ed.), Language, Thought, and Culture. Advances in the Study of Cognition (pp. 1-55). New York: Academic Press.

Saussure, F. de (1985). Cours de Linguistique Générale. Paris: Payot.

Schank, R.C. and R.P. Abelson (1977). Scripts, Plans, Goals and Understanding. An Inquiry into Human Knowledge Structures. Hillsdale, N.J.: Lawrence Erlbaum.

Schegloff, E.A. (1991). Reflections on talk and social structure. In D. Boden and D.H. Zimmerman (Eds.), Talk and Social Structure: Studies in Ethnometodology and Conversation Analysis (pp. 44-71). Cambridge: Polity Press.

Simmel, G. (1998). Sociologiens problem. In G. Simmel, Hvordan er samfundet muligt? (pp. 1928). København: Gyldendal.

Sklovskij, V. (1969). Die Kunst als Verfahren. In J. Striedter (Ed.), Texte der Russischen Formalismus, I: Texte zur allgemeinen Literaturtheorie und zur Theorie der Prosa (pp. 3-35). München: Fink.

Sørensen, A.S., O.M. Høystad, E. Bjurstrøm and H. Vike (2008). Nye kulturstudier. En innføring. Oslo: Spartacus.

Tyler, E.B. (1873). Primitive Culture. London: Watts.

Vygotsky, L.S. (1978). Mind in Society. The Development of Higher Psychological Processes. Cambridge, Mass.: Harvard University Press.

Williams, R. (1958). Culture and Society, 1780-1950. London, New York: Columbia University Press.

\footnotetext{
${ }^{1}$ En af artiklens forfattere var deltager i denne interaktion. Dialogen er nedskrevet efter hukommelsen umiddelbart efter hændelsen (jf. også Frimann 2004: 110). Registrering af data er således baseret på feltnotater (Kruuse, 1999:138), hvis største fejlkilde er, om forskeren husker og præcist kan gengive interaktionen i alle dens detaljer uden unøjagtigheder, udeladelser eller tilføjelser i form af tolkninger og selektiv perception. Forskerens rolle har været den fuldstændige deltager (Buford Juncker, 1960), hvor det var skjult for forsøgspersonen, at deltageren var i gang med dataindsamling. Denne dataindsamlingsmetode er ofte forbundet med etiske problemstillinger, især når data offentliggøres. I denne case har vi minimeret det etiske aspekt ved at anonymisere ekspedientens identitet, benzinselskabet og tankstationens geografiske placering. Interaktionen består af en enkelt case (Kruuse, 1999:63), som udgør en enkelt analyseenhed. Potentielt rejser casestudiet spørgsmålet, om den udvalgte case er eksemplarisk
} 
og gælder for et stort antal lignende tilfælde, eller om der er tale om et særtilfælde. Vi mener, at denne case er eksemplarisk. For at underbygge denne påstand har vi kontaktet det pågældende benzinselskab, som har bekræftet, at ekspedienter får kurser i at kommunikere i ekspeditioner ud fra selskabets eget koncept. Det omfatter bl.a. tiltaleformer, interaktion, forløb og ordvalg. 2 Tankstationens evolution hen imod den moderne servicestation har sit modsvar i forvandlingen af tankpasserens arbejdsfunktioner. Indtil 1970erne stod tankpasseren for al kundekontakt: benzinpåfyldning, olieeftersyn, afregning. I en overgangsfase blev afregning forlagt til hovedbygningen, hvilket befordrede udviklingen af andre salgstilbud på stedet. Da stationerne alle var blevet overdækket kunne tankpasseren definitivt rykke indendørs - på museet. Tankpasserens særlige kompetencer er distribueret til den opkvalificerede kunde og den nedkvalificerede ekspedient.

${ }^{3}$ I det efterfølgende ser vi bort fra de øvrige episoder i storsyntagmet. Analysen er baseret på den funktionelle grammatik, som den udfoldes hos Hasan (1985). Vi analyserer kun interaktionens verbalsproglige forløb. Gestik, prosodi o.l. er således udeladt ${ }^{4}$ Afvisning af salgsforespørgslen sker af samme grund kun, hvis butikken ikke har den efterspurgte vare. Med til SA hører også, at ekspedienten tilbyder yderligere varer 'ellers andet?'. Det er faktisk den vigtigste funktion for SA, som udspringer af den asymmetriske rolleforfordeling mellem kunde og ekspedient. Disse roller betyder at ekspedienten skal være tilgængelig og tilbyde varer, så længe kunden ønsker det.

$5 \wedge$ angiver at et element kommer strukturelt før et andet. Det, står til venstre for ${ }^{\wedge}$ skal optræde før det, der står til højre for tegnet.

${ }^{6}$ Forklaringen af de symboler, der er anvendt til notation af strukturen. 1)^ betyder at elementet før og efter symbolet skal forekomme i den rækkefølge, 2) (X) parentes om et element betyder, at det er valgfrit. 3) - prikken betyder, at der er mere end en valgmulighed i sekvensen, dvs. at element $\mathrm{H}$ og/eller SI kan vælges, og hvis begge er valgt i situationen kan rækkefølge vælges frit SI, H eller SI, H. 4) [XX] kantet parentes markerer, at sekvensen i den kantede parentes er bundet til at optræde på denne plads i strukturen. 5) $\triangle$ Den buede pil markerer gentagelse. 6) $\{X Y\}$ Klammeparentesen markerer at gentagelsen af elementerne inden for parentesen skal være ensartet, sådan at hvis der eksempelvis optræder tre SF elementer, så skal der også forekomme $3 \mathrm{SA}$ elementer.

${ }^{7}$ En kritisk indvending mod dette ideal kunne være, at den maskerer den ulighed, som er indbygget i situationen, hvor den ene part skal betjene den anden, som kan lade sig betjene, men også kan vælge ikke at købe noget. Desuden er den tjenende rolle i denne situation lavt betalt og nyder ingen social status pga. manglende formel ekspertise.

${ }^{8}$ Vores forespørgsel til benzinselskabet har i øvrigt efterfølgende givet os viden om, at ekspedientens valg i situationen var obligatorisk. Høflighedsformerne var led i selskabets forsøg på at designe kommunikationen på en 'kundevenlig' måde.

\section{Forfatterne}

Søren Frimann er lektor på Institut for Kommunikation, Aalborg Universitet. Email: frimann@hum.aau.dk

Christian Jantzen er lektor og institutleder på Institut for Kommunikation, Aalborg Universitet. Email: jantzen@hum.aau.dk 